\title{
Gambaran pengetahuan siswa kelas XII SMA Negeri 7 Manado terhadap miopia
}

\author{
${ }^{1}$ Viany S. H. Lupa \\ ${ }^{2}$ J. S. M. Saerang \\ ${ }^{2}$ Yamin Tongku
}

\author{
${ }^{1}$ Kandidat Skripsi Fakultas Kedokteran Universitas Sam Ratulangi Manado \\ ${ }^{2}$ Bagian Ilmu Kesehatan Mata Fakultas Kedokteran Universitas Sam Ratulangi \\ Email: vianyheidy@yahoo.com
}

\begin{abstract}
Nearsightedness is a refractive disorder which is the rays enter the eye without accommodation and will be refrated in the front of retina. Nearsightedness is one of the causes of low vision in children. Eye health in school student is important in learning activities. Many students do not understand the importance of knowledge towards nearsightedness. Knowledge is a very important domain that will affect an action. This was a descriptive study. This study aimed to determine the description of student grade XII knowledges at SMA Negeri 7 Manado towards nearsightedness. The results showed that the level of knowledge of student grade XII of SMA Negeri 7 Manado towards nearsightedness was still considered enough with a percentage of $56 \%$.
\end{abstract}

Keywords: knowledge, student, nearsightedness

\begin{abstract}
Abstrak: Miopia adalah suatu kelainan refraksi dimana sinar-sinar sejajar masuk ke bola mata tanpa akomodasi akan dibiaskan di depan retina. Miopia adalah salah satu penyebab penurunan ketajaman penglihatan pada anak-anak. Penglihatan yang baik sangat penting dalam proses belajar mengajar. Banyak pelajar yang belum memahami pentingnya pengetahuan tentang miopia. Pengetahuan merupakan domain yang sangat penting untuk terbentuknya tindakan seseorang. Jenis penelitian ini deksriptif. Penelitian ini bertujuan untuk mengetahui gambaran pengetahuan siswa kelas XII SMA Negeri 7 Manado terhadap miopia. Hasil penelitian menunjukkan bahwa tingkat pengetahuan siswa kelas XII SMA Negeri 7 Manado terhahap miopia masih dianggap cukup dengan persentase sebesar 56\%.
\end{abstract}

Kata kunci: pengetahuan, siswa, miopia

Penglihatan adalah salah satu aspek yang sangat penting dalam kehidupan. Terdapat lima jenis sdpenyakit mata tersering di Indonesia yaitu kelainan refraksi, konjungtivitis, pterigium, katarak, dan glaukoma. ${ }^{1,2}$

Kelainan refraksi mata adalah suatu keadaan dimana bayangan tegas tidak dibentuk pada retina tetapi di bagian depan atau belakang bintik kuning dan tidak terletak pada satu titik yang tajam. Kelainan refraksi yang tidak terkoreksi merupakan penyebab utama penurunan ketajaman penglihatan di dunia dan dapat menyebabkan kebutaan. ${ }^{3}$

Angka kejadian kelainan refraksi cukup tinggi. Di dunia kelainan refraksi merupakan penyebab utama kebutaan ketiga yaitu $0,14 \%$ setelah katarak $(0,78 \%)$ dan glaukoma $(0,20 \%){ }^{4}$ Berdasarkan data dari WHO prevalensi kelainan refraksi pada umur 5-15 tahun sebanyak 12,8 juta orang $(0,97 \%){ }^{5}$ Data dari VISION 2020, suatu program kerjasama antara International Agency for the Prevention of Blindness (IAPB) dan WHO, menyatakan 
bahwa pada tahun 2006 diperkirakan 153 juta penduduk dunia mengalami gangguan visus akibat kelainan refraksi yang tidak dikoreksi. $^{6}$

Di Indonesia, prevalensi kelainan refraksi menempati urutan pertama pada penyakit mata dan ditemukan jumlah penduduk kelainan refraksi hampir 25\% populasi penduduk atau sekitar 55 juta jiwa. Tiga jenis kelainan refraksi yang paling sering dijumpai yaitu miopia, hipermetropia, dan astigmatisma. ${ }^{7}$

Miopia (nearsightedness) adalah suatu kelainan refraksi dimana sinar-sinar sejajar masuk ke bola mata tanpa akomodasi akan dibiaskan di depan retina. Menurut perhitungan WHO, tanpa ada tindakan pencegahan dan pengobatan terhadap miopia, mengakibatkan jumlah penderita akan semakin meningkat. Dan berdasarkan laporan Institute of Eye Research diperkirakan pada tahun 2020 penderita miopia akan mencapai 2,5 milyar penduduk. ${ }^{8,9}$

Prevalensi penderita miopia pada beberapa kelompok etnis sangat bervariasi. Pada umumnya berkisar antara 15-18\% dari seluruh populasi. Angka tertinggi pada orang asia dan paling sedikit pada orang kulit hitam. Prevalensi penderita miopia juga tinggi pada kelompok orang dengan tingkat sosial ekonomi yang tinggi. ${ }^{10,11}$

Miopia adalah salah satu penyebab penurunan ketajaman penglihatan pada anak-anak, sedangkan penglihatan yang baik sangat penting dalam proses belajar mengajar. Dewasa ini terjadi kecenderungan peningkatan prevalensi miopia diberbagai belahan dunia terutama di asia dan peningkatan prevalensi miopia sangat menonjol pada anak-anak usia sekolah. ${ }^{12}$

\section{METODE PENELITIAN}

Jenis penelitian yang dilakukan ialah deskriptif yang bertujuan untuk menggambarkan pengetahuan siswa SMA Negeri 7 Manado terhadap miopia. Penelitian ini dilaksanakan pada bulan November 2015 dan tempat penelitian di SMA Negeri 7 Manado. Populasi penelitian ialah siswa kelas XII SMA Negeri 7 Manado. Sampel penelitian diambil dari sebagian populasi yang sesuai dengan kriteria inklusi, seperti siswa kelas XII SMA Negeri 7 Manado yang hadir, bersedia dengan sukarela untuk dijadikan subjek dalam penelitian ini, dan bersifat kooperatif selama pengambilan data

\section{HASIL PENELITIAN}

Kuesioner dibagikan pada sebagian populasi yang memenuhi kriteria inklusi dan diperoleh sebanyak 81 responden. Tiga responden termasuk kriteria eksklusi, sehingga subjek penelitian menjadi 78 responden.

\section{Pengetahuan siswa berdasarkan jenis kelamin responden}

Tingkat pengetahuan responden berdasarkan jenis kelamin didapatkan pada responden perempuan tergolong kurang 38,8\% dan responden laki-laki tergolong sangat kurang 19,4\% (Tabel 1).

Tabel 1. Distribusi tingkat pengetahuan responden berdasarkan jenis kelamin

\begin{tabular}{cclcc}
\hline $\begin{array}{c}\text { Jenis } \\
\text { kelamin }\end{array}$ & $\begin{array}{c}\text { Jumlah } \\
\text { responden }\end{array}$ & $\begin{array}{l}\text { Hasil } \\
\text { skoring } \\
\text { responden } \\
\text { yang } \\
\text { menjawab } \\
\text { tahu }\end{array}$ & Kategori \\
& 30 & 151 & 19,4 & $\begin{array}{l}\text { Sangat } \\
\text { kurang } \\
\text { L }\end{array}$ \\
P & 48 & 303 & 38,8 & Kurang \\
\hline
\end{tabular}

\section{Pengetahuan siswa berdasarkan usia}

Pengetahuan responden berdasarkan usia didapatkan usia 16 tahun berpengetahuan sangat kurang 19,6\%, umur 17 berpengetahuan kurang 38,1\%, dan umur 18 tahun berpengetahuan sangat kurang $0,6 \%$.

\section{Pengetahuan siswa berdasarkan kelas jurusan}

Tingkat pengetahuan responden berdasarkan jurusan didapatkan responden jurusan MIA berpengetahuan kurang 35\%, responden jurusan IS berpengetahuan 
kurang 20,3\%, dan responden jurusan IB berpengetahuan sangat kurang 4,1\%.

Tabel 2. Distribusi tingkat pengetahuan responden berdasarkan usia

\begin{tabular}{ccccc}
\hline Usia & $\begin{array}{l}\text { Jumlah } \\
\text { Responden }\end{array}$ & $\begin{array}{l}\text { Hasil } \\
\text { skoring } \\
\text { responden } \\
\text { yang } \\
\text { menjawab } \\
\text { tahu }\end{array}$ & $\%$ & Kategori \\
\hline 16 & 27 & 153 & 19,6 & $\begin{array}{l}\text { Sangat } \\
\text { kurang }\end{array}$ \\
17 & 49 & 297 & 38,1 & $\begin{array}{l}\text { Kurang } \\
\text { Sangat } \\
\text { kurang }\end{array}$ \\
\hline
\end{tabular}

Tabel 3. Distribusi tingkat pengetahuan responden berdasarkan kelas jurusan

\begin{tabular}{ccccc}
\hline $\begin{array}{l}\text { Kelas } \\
\text { Jurusan }\end{array}$ & $\begin{array}{l}\text { Jumlah } \\
\text { Responden }\end{array}$ & $\begin{array}{l}\text { Hasil skoring } \\
\text { responden } \\
\text { yang } \\
\text { menjawab } \\
\text { tahu }\end{array}$ & Kategori \\
\hline MIA & 44 & 273 & 35 & Kurang \\
IS & 28 & 159 & 20,3 & Kurang \\
IB & 6 & 32 & 4,1 & $\begin{array}{l}\text { Sangat } \\
\text { kurang }\end{array}$ \\
\hline
\end{tabular}

\section{BAHASAN}

\section{Karakteristik responden}

Responden dalam penelitian ini berjumlah 78 orang, sebagian besar berjenis kelamin perempuan dengan jumlah 48 orang $(61,5 \%)$, sedangkan responden yang berjenis kelamin laki-laki sebanyak 30 orang (38,5\%). Berdasarkan tingkat pengetahuan yang diteliti diketahui tingkat pengetahuan perempuan tergolong kurang dan tingkat pengetahuan laki-laki tergolong sangat kurang.

Berdasarkan usia yang diteliti, sebagian besar responden berusia 17 tahun sebanyak 49 orang $(62,8 \%)$, selanjutnya usia 16 tahun sebanyak 27 orang (36,6\%), dan yang paling sedikit berusia 18 tahun sebanyak 2 orang (2,6\%). Tingkat pengetahuan responden yang berusia 16 tahun tergolong sangat kurang, usia 17 tahun tergolong kurang, sedangkan usia 18 tahun tergolong sangat kurang.

Berdasarkan kelas jurusan responden yang di teliti, sebagian besar ialah jurusan
MIA sebanyak 44 orang (56,4\%), selanjutnya responden jurusan IS sebanyak 26 responden $(35,8 \%)$, dan yang paling sedikit ialah responden jurusan IB berjumlah 6 responden (7,8\%). Berdasarkan tingkat pengetahuan yang diteliti diketahui responden jurusan MIA dan IS tergolong kurang, sedangkan responden jurusan IB tergolong sangat kurang.

\section{Pengetahuan siswa kelas XII SMA Negeri 7 Manado terhadap miopia}

Pengetahuan merupakan salah satu faktor yang berperan dalam pengembangan kesehatan seseorang. Semakin banyak pengetahuan seseorang terhadap miopia maka semakin baik tingkat kesehatan yang dimiliki orang tersebut. Berdasarkan penelitian yang di lakukan di SMA Negeri 7 Manado didapatkan bahwa pengetahuan siswa terhadap miopia tergolong cukup, dengan persentase sebesar $56 \%$.

\section{SIMPULAN}

Berdasarkan hasil penelitian dan bahasan dapat disimpulkan bahwa, pengetahuan siswa kelas XII SMA Negeri 7 Manado terhadap miopia masih tergolong cukup (56\%).

\section{DAFTAR PUSTAKA}

1. Ratanna R, Rares L, Saerang J. Kelainan refraksi pada anak di BLU RSU Prof. Dr. R. D. Kandou. e-Clinic. 2014;2(2):2.

2. Smec group. 5 penyakit mata tersering di Indonesia. 25 April 2014. [cited 1 Oct 2015]. Available from: http://smecgroup.com/news.php?extend.55.

3. Ilyas S. Ilmu Penyakit Mata (4th ed). Jakarta: FKUI, 2012.

4. Komariah C, Wahyu N. Hubungan status refraksi, dengan kebiasaan membaca, aktivitas di depan komputer, dan status refraksi orang tua pada anak sekolah dasar. Jurnal Kedokteran Brawijaya. 2014;28(2):1-4

5. Resnikof S. Global data on visual impairment in the year 2002. Bulletin of the World Health Organization. 2004;82(11).

6. Hutahuruk M. Hubungan antara 
pengetahuan dengan sikap orangtua tentang kelainan refraksi pada anak. Semarang: $\quad$ FK Universitas Diponegoro; 2009.

7. Ariestanti H, Anom S, Dewayani P. Characteristic of patients with refractive disorder at Eye Clinic of Sanglah General Hospital Denpasar, Bali-Indonesia Period of 1st January - 31st December 2011. Bali Medical Journal (BMJ). 2012;1(3):101-7.

8. Saw S, Hong R, Zhang M, Fu Z, Ye M, Tan D, Chew S. Near work activity and myopia in rural and urban schoolchildren in China. Journal Pediatric Ophthalmology Strabismus, 2001. [cited 1 Oct 2015]. Available from: http://www.ncbi.nim.nih.gov

9. Mutti D, Mitchell G, Moeschberger L, Jones L, Zadnik K. Parental myopia, near work, school achievement, and children's refractive error. Investigative Ophthalmology \& Visual Science. 2002;43(12):3633-40.

10. Ballantyne A, Michaelson I. Textbook of the Fundus of the Eye (2nd ed). Baltimore: The Williams and Wilkin, 1973.

11. Fong D, Pruet R. Systemic association with myopia. In: Albert D, Jacobiec F, editors. Principles and Practice of Ophthalmology. Clinical pratice. Philadelphia. 1993;225(2):3142-44.

12. Usman S, Nukman E, Bebasari E. Hubungan antara faktor keturunan, aktivitas melihat dekat dan sikap pencegahan mahasiswa fakultas kedokteran universitas riau terhadap kejadian miopia. Jurnal Kedokteran Universitas Riau. 2014;1(2):1-13. 